\title{
CENTRE FOR CROSS-CULTURAL RESEARCH ON WOMEN, OXFORD
}

This Centre was established at Queen Elizabeth House, Oxford, in 1983 to consolidate and advance the research activities in which certain members of the House have been engaged for more than a decade. It also includes as Associate Members certain Visiting Fellows of the House working in appropriate fields of study. The Centre supports the Oxford Women's Social Anthropology Seminar, which was founded by some of its members and has been held at Queen Elizabeth House since 1973. Workshops on particular themes are held from time to time and a series of publications has been established, the first volume appearing in summer 1984. The Centre's research themes fall into four broad headings: social, political and economic issues; historical studies of women; Third World literature; theoretical issues in women's studies.

The Centre has now decided to establish a series of special lectures in honour of scholars who have made important contributions to the study of women in the Third World. Two of these are named after women anthropologists who have done distinguished work in Africa: Audrey Richards [of whom an appreciation will appear in the next issue of Africa - Ed.] and Phyllis Kaberry. It is hoped to attract donations and support from their professional colleagues. Donations should be sent to (and further information may be received from) the Director of the Centre, Dr Shirley Ardener, at: Queen Elizabeth House, St Giles, Oxford OX1 3LA (Tel: 0865-52952).

\section{GERONTOLOGIE AFRICAINE/AFRICAN GERONTOLOGY}

We have received the first issue of this news bulletin from J. Flesch, President of the Centre Internationale de Gerontologie Sociale, based in Paris. It arises out of the 1982 World Assembly on Ageing organized at Vienna by the United Nations, at which African countries made up a third of all participants. This Assembly adopted an International Plan of Action on Ageing, and an African conference is taking place in Dakar in December 1984 to encourage implementation of the plan and the formation of an African Society of Gerontology. The prime objective of African Gerontology is to inform all those involved with ageing and the aged - politicians, officials, physicians, researchers, social and relief workers etc. - of research completed or in progress, the current situation and forecasts in any of the fields pertinent to gerontology (medicine, demography, economics, sociology, psychology, etc.). Further details from J. Flesch, Centre Internationale de Gerontologie Sociale, 91 rue Jouffroy, 75017 Paris (tel: 766.52.36).

\section{COLEGIO MAYOR NUESTRA SEÑORA DE AFRICA}

We have received notice of this university college in Madrid from its Director, Dr Luis Beltrân. The Colegio Mayor exists as a residential and study centre, particularly for students from Equatorial Guinea and other African countries pursuing university courses in Madrid. It is directly linked to the Spanish Ministry of Foreign Affairs and its Office for Cooperation with Equatorial Guinea, as well as with the University. The Colegio Mayor was reorganized in 1981 to promote African studies and research, and its new programme has been implemented since 1983. Further information may be had from the Director, Colegio Mayor N.S. de Africa, Calle Obispo Trejo No. 1, Madrid 3, Spain. 